\title{
THE EFFECT OF CROSSWORD TECHNIQUE ON STUDENTS' VOCABULARY MASTERY
}

\author{
Rabi'ah \\ robiah_43@yahoo.com \\ IAIN MADURA
}

\begin{abstract}
Having many vocabularies is very important in learning English. Vocabulary is one of factors that determines the success of four English Skills. The students who have enough vocabulary could be easier in learning English. From this reason, the teacher should give a good technique to teach vocabulary. Crossword technique is one of an interesting, enjoyable, and fun that should be used by the teacher. Crossword technique is also effective in enrich students' vocabulary. By implementing the crossword technique the students don't feel memorizing the vocabularies, they could add their vocabulary unconsciously. This study is aimed to find the effect of crossword technique on students' vocabulary mastery. It was done at MTs Miftahul Ulum Palengaan Pamekasan. The participant is the seventh grade students. The total number of the participant is 20 students. This study was quantitative research and quasi experimental as the design. Vocabulary test was used to collect the data which consist of 50 questions. The form of test was multiple choice test. There were two tests, namely pretest and posttest. Pretest was done before giving treatment and posttest was done after giving treatment. To achieve the objective of this study the data were analyzed by using dependent $t$ test with the help of SPSS 20. The result turned out to test the hypothesis which states students score in the posttest are different from their score in the pretest. The finding showed that the alternative hypothesis is accepted. It was proven by the result of computation of t-value is higher than critical 0.05 with $\mathrm{df} 19$.It means that the alternative hypothesis (Hi) was accepted. From those explanations above, it could be concluded that there is significant effect of crossword technique on the first grade students' vocabulary mastery at MTs Miftahul Ulum Gunung Tangis Palengaan Pamekasan. Therefore, teaching vocabulary by using crossword technique was more effective than teaching vocabulary conventionally.From this finding, the researcher suggests for the English teacher to use crossword technique in teaching vocabulary because this technique is very enjoyable and interesting for the students. Moreover, for the institution who doesn't have enough facilities.
\end{abstract}

Key words: Crossword Technique, Vocabulary Mastery

\section{INTRODUCTION}

In English teaching, there are four language skills that need to be mastered by the students "the first falls into listening and reading while the latter comprises speaking and writing (Wilkins:2005). Besides someone should have wide vocabularies to support them to be able to use a certain language in the four of English skill namely listening, reading, speaking, and writing well. Mastering academic vocabulary helps students comprehend content in the classroom and raise their scores on standardized tests.

Vocabulary is one important aspect in learning a foreign language. With a limited vocabulary anyone will also has limited understanding in terms of reading and listening, and they also get difficulty in productive skill such as speaking and writing. It is true that it might be impossible to learn a language without vocabulary ability. The acquisition of a large number of vocabularies can help the students to speak, listen, read and write. A good vocabulary and ability to use words correctly and effectively can help the students make school work easier and more rewarding and also many tests that they take in school include vocabulary questions. The more vocabulary they know the better their chance to do well on an English test. 
In secondary education level or let's say in Junior High School, the students are expected to master a vocabulary of 30004000 words. It is not clear; however, to what basis the vocabulary mastery is measured. Ideally, mastering 3000-4000 English words means that the Junior High School students are able to use the English language communicatively in their daily life (Thornburry:2002).

Associated with the importance of vocabularies, there are a huge number of words in the language and it is impossible for the teacher to teach more than a fairly small portion of them. A teacher seems should give vocabularyy to their students appropriate with students need and level in one side and while in another side they are supposed to select the technique in teaching vocabulary to their pupils in order that they have wide vocabularies as their level and their need of the vocabularies. In contrast, the students in MTs. Miftahul Ulum Gunung Tangis Palengaan Pamekasan have limited vocabulary so that they find it difficult in learning English. Their achievements in English skills are also low, even in speaking, reading, writing moreover in listening. In the process of teaching and learning, teacher often finds situation when students are not enthusiastic in learning because they got bored. If they are bored, they will be difficult to concentrate and participate in the classroom activity. This condition is also caused by the less of some fasilities such as the availability of the media for teaching and learning. So, crossword technique is the appropriate technique for this condition because it doesn't need any facilities and equipments to do the activities, only chalk and blackboard that is needed in this technique.

Remembering the importance of vocabulary for English learner, so as the teacher should look for a fun technique to teach vocabulary. Here the researcher examined the crossword method, whether this method would be success or not. Crossword technique is one of games that treat the students in interesting condition to learn English, especially in acquiring a number of vocabularies. The crossword technique offers a challenge that will motivate the students to try to fulfill the form of puzzle in the white board. It gives much opportunity for the students to practice and repeat the sentence pattern and vocabulary. Beside, the crossword puzzle is a kind of games that makes the teaching-learning process more attractive than before. The students feel fun, relaxed and enjoyable, and they remember the vocabulary in different way.

The main considaration the researcher conducts the study. The researcher found the students have probelm in vocabulary mastery. They have limited vocabularies in learning English. Crossword technique is suitable with students condition and institution which has limited facilities. While for crossword puzzle, it need much cost to apply the teachnique.

In English language teaching, there are four aspects that should be mastered by the students. One of those aspects is vocabulary. Vocabulary is one of important aspects in learning a foreign language. As stated by Edward (1997:149) in his book that "Vocabulary is one of the important factors in all language teaching, student must continually be learning words as they learn structure and as they practice sound system".

With limited vocabulary, students will also have limited understanding in terms of speaking, reading, listening, and writing. On the other hand, Wilkins (2002:13) states "Vocabulary learning is very important 'Without grammar very little can be conveyed, without vocabulary nothing can be conveyed'".

This is how the linguist David Wilkins summed up the use of vocabulary learning. The statement could be meant if the students spend most of their time studying grammar, their English will not improve very much. They would see most improvement if they learn more words and 
expressions or it is also called vocabulary. In line with this, Palmer (1986:32) states that "vocabulary was one of the most important aspects of foreign language learning".

From the statement above it is stated clearly that vocabulary plays the most important role in learning second or foreign language. Students can speak, write, read, and even listen in English, of course, by having much vocabulary as well as possible because if they want to communicate with others in certain language, they must master the language they belong to especially to know enough vocabulary of those languages. Without vocabulary, they cannot communicate and express their idea too effectively.

Learning the new vocabulary does not only mean memorizing the form of the word but also understand its meaning. Mastering vocabulary can help the students to enjoy their classes. One who masters enough vocabulary will find fewer difficulties than those who have fewer vocabularies. When they read a certain text, they will easily get the information from it since they can understand every word in the text. On the other hand, those who lack of vocabulary will face a lot of problems. In line with this, Pora (2001:7) states that vocabulary mastery is absolutely possessed by someone that wants to understand English reading text and English conversation. So, mastery of vocabulary is really important in any language learning that will be useful for the process of achieving languageteaching objectives.

Besides that, by mastering vocabulary the students will know the meaning of vocabulary in and out the context without often using dictionary or the translation of the word which is provided by the teacher and make the students more interested and active in teaching learning process. So, by realizing the importance of vocabulary development or vocabulary mastery in learning a second language, students must devote part of their time to learn vocabulary items.

\section{The Advantages of Crossword Technique}

Like my explanation above crossword technique is very an interesting way to teach vocabulary. It is very useful for the students. From this technique they can study English happily and easily. The use of crossword game in teaching vocabulary is one of the alternative techniques to help the students construct and improve their vocabulary mastery. Moreover, crossword can be one of activities in practicing vocabulary which can help the students to be more familiar with the words, recognize the words, manipulate and remember the words.

The other advantage of crossword technique is to avoid teaching monotonously, so the students are not bored to study English in the classroom. Working the crossword game in a group and in relax atmosphere will make the students feel fun and enjoy in learning. This is meaningful and helpful in learning a language and it can encourage all of the students to participate in learning process.

Some writers have attempted to give a rationale for the use of crosswords in L2 learning. Bressan (1970:94), for example, lists five benefits which can accrue from using crosswords in the language class:

1. Vocabulary building is the most obvious. Here, not only can previous knowledge be consolidated, but there can also be an acquisition of new forms and structures.

2. Orthography is also an important area, since the solution to a puzzle is based on the correct spelling of the answers.

3. Crossword puzzles can also develop and test the student's knowledge of morphology, through the use of items dealing with verb endings, prefixes, suffixes and the like.

4. Since abbreviations also occur in puzzles, this presents an opportunity to review them or introduce new ones. 
5. Finally, many puzzle clues test general knowledge of a historical and cultural nature.

\section{The Procedure of Crossword Technique}

The teacher writes a factory word in the middle of the board for example hospital. Then have student 1 to think of another factory word that can be linked vertically through a shared letter with the word on the board. The student gives a clue or definition of that word and tells the number of letters in the word and its first letter. Student 2 comes to the board and writes the word so that it crosses the first word vertically. Using shared letter, student 2 then think that word that can be linked horizontally through a shared letter with the second word and give clue for that word. Student 3 comes to the board and writes the word so that it crosses the second word horizontally using the shared letter. The activity continues with student alternating vertical and horizontal linking word.

\section{METHOD}

The research design of this study is quasy experimental with non-randomized pretest and post test design. It means that the reseracher only uses one group to be experimeted. One group was given test twice nemelly pretest and posttest to know the result of the treatment. The test is vocabulary test in form of multiple choice test. Because the test is made by the researcher, the test was tried out to the other students with different school. The purpose is to know the reliability of the test. the result showed that the test was reliable. The material involved public places, profession, descriptive adjective, thing in the classroom, family and humand performance. And the test covers all of the materials.

After giving pretest, the researcher conducting treatment by giving crossword technique to teach vocabulary. The treatment was giving four times.After that, the researcher conduct post test to know the result of the treatment.

\section{RESULTS}

Paired Samples Test

\begin{tabular}{|c|c|c|c|c|c|c|c|c|c|}
\hline & & \multicolumn{5}{|c|}{ Paired Differences } & \multirow{3}{*}{\multicolumn{2}{|c|}{$\mathrm{t} \quad \mathrm{df}$}} & \multirow{3}{*}{$\begin{array}{l}\text { Sig. } \\
(2- \\
\text { tailed) }\end{array}$} \\
\hline & & \multirow[t]{2}{*}{ Mean } & \multirow[t]{2}{*}{$\begin{array}{l}\text { Std. } \\
\text { Devia } \\
\text { tion }\end{array}$} & \multirow[t]{2}{*}{$\begin{array}{l}\text { Std. } \\
\text { Error } \\
\text { Mean }\end{array}$} & \multicolumn{2}{|c|}{$\begin{array}{c}95 \% \\
\text { Confidence } \\
\text { Interval of the } \\
\text { Difference }\end{array}$} & & & \\
\hline & & & & & Lower & Upper & & & \\
\hline $\begin{array}{l}\text { Pair } \\
1\end{array}$ & $\begin{array}{l}\text { Pre } \\
\text { test } \\
- \\
\text { post } \\
\text { test }\end{array}$ & $22.300^{-}$ & 7.533 & 1.684 & $25.82 \bar{\sigma}^{-}$ & 18.774 & $13.239^{-}$ & 19 & .000 \\
\hline
\end{tabular}

Based on the data above it can be stated that alternative hyphothesis ( $\mathrm{Ha})$ which states "students score in the posttest are different from their score in the pretest is excepted and null hypothesisi is rejected. It is proven by the value of sig is 0.000 that less than 0.05. In short, crossword technique has significant effect to the students' vocabulary mastery. It means that, students' vocabulary gets improved after they are taught by crossword technique.

\section{DISCUSSION}

This section discusses the research findings in relation to the theory and previous study. Based on the research finding, it can be concluded that crossword technique is very intersting and effective to improve students' English vocabulary. It proven by the result of students' score in pretest and posttest that significantly different. Moreover, when the researcher implements the technique the students are very enthusiastic to follow the teaching and learning process.

In line with the researcher piont of view, weinstein (2004:3) say that with crossword puzzle students can see the challangeing from the beginning to the end. And when they fill in the last square, they know that they have perfect solution and it is satisfying feeling. Further, he said that it is good way for learning vocabulary words. According to Hornby (1985:959) crossword puzzle is a puzzle or wordplay in which word has to be written from numbered clues vertically and horizontally in spaces on a square or blong. But, 
different fro crossword puzzle, crossword technique is more simple. It doesn't need puzzle. It used activity that similar with crossword puzzle.

From point of view above, crossword technique can be recommended as a classroom activity to facilitate the development of students' vocabulary mastery. For example, when the students fiil in the word in the form of box on the blackboard each students will contribute new vocabulary to their group.

Crossword technique has been one of popular games in language teaching. The use crossword is interesting and chellenging thus gains more attention of the learners. This technique is learner centerd and need little intervention from the teacher. It is suitable for many different types or levels of the learners.

Based on the finding of this research, the researcher concluded that crossword technique can be alternative way to improve students' vocabulary mastery. By applying crossword technique in the class, the students fell enjoy and relax in learning vocabulary without memorizing them.

\section{CONCLUSIONS AND SUGGESTIONS}

Based on the research finding, theories and disscussion presents in previous sections, the researcher concluded some points concerning with the effect of crossword technique on students' vocabulary.

Firstly, based on the research finding, it could be said that crossword technique gives effect on students' English vocabulary mastery because in this technique the students are learning by doing. As we know that learning by doing is more meaningful in their learning. Because they fill the crossword by them selves, students try to find the new vocabulary by initial of the latter. It is proven by the improvement of students' score post test. This technique also can solve the problem monotonous and boring class. It is showed by the high of participant of the students in the process of teaching and learning or working crossword in group and in the relax atmosphere make the students fell fun and enjoy in learning. This is meaningful and helpful in learning a language and it can encourage all of the students to participate in disscussion.

The use of crossword teachnique in teaching English provided some benefits for process of teaching and learning itself. Such as that enjoyable, motivating challeging and encouraging. The other benefit is crossword technique doesn't need much cost and media. So it is suitable for the institution which doesn't have enough facility.

There are some suggestions proposed for the teacher, for the students, and for further researcher. For the teacher, it is suggested to use various methods to make students more encouraged to improve learning process. They should enhance their ability in teaching english especially when they taught vocabulary beacause most of students are lazy to memorize words. So that, crossword technique is one of recommanded teachniques to teach vocabulary, more over this technique doesn't need much equipment to be implemented in the class.

For the students, it is suggested that the students are expected to be more motivated in learning English. They can study English by using crossword in their house.

The last is for futher resaecher, The researcher would like to suggest to other researcher, that the result of the study can be used as editional references for futher researcher with different design and limitation.

\section{REFERENCES}

\author{
Betridge, 1984. Game for language \\ learning. Second edition. \\ Cambridge: cambridge university
}


Bressan, D. (1970). Crossword puzzles in modern language teaching. Audio-Visual Language Journal, 8(2), 93-95.

Edward, A. and Rebecca, M. Vallete. 1997. Classroom Technique. Foreign Language and English as a Second Language. New York: Harcout Brave Javanovich.

Thornburry, S. 2002. How to Teach Vocabulary. England: Pearson Education Limited.
Hornby, 1987. Advances learners dictionary of English. Oxfort University press

Weinstein, E. 2004. Millions Keesp Mind Sharp. (http://www.primate.wisc.edu/people , accessed on 28 March 2018)

Pora, Y. 2001. Enrich Your Vocabulary Through Readings and Idioms. Yogyakarta: Pustaka Pelajar.

Wilkins, P. 2005. Learning to Teach English. England: Delta Publisher. 